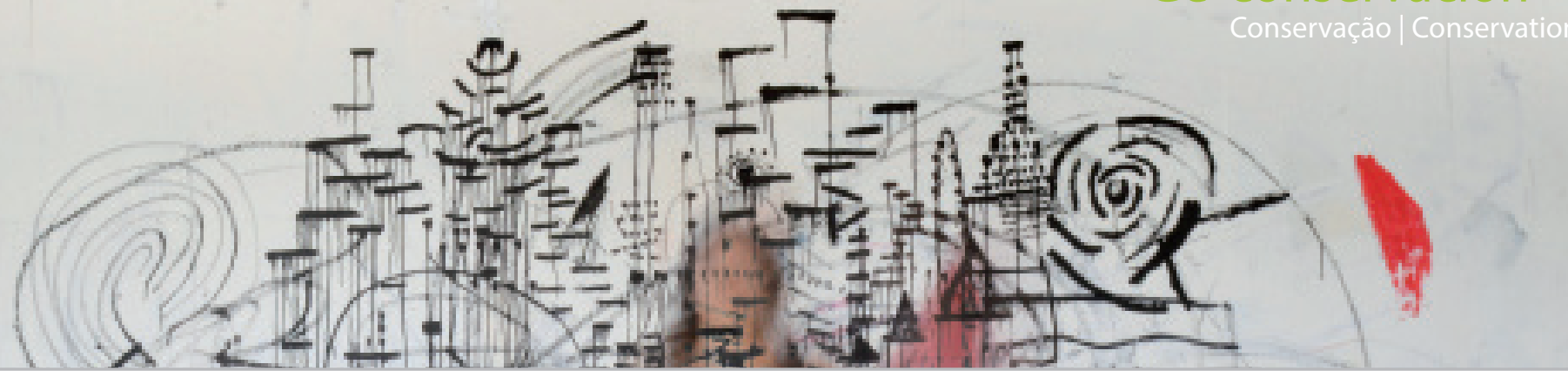

\title{
Conservación Preventiva Activa, Creación de estrategias de prevención a través del trabajo directo con Ixs artistas
}

\author{
Ruth del Fresno-Guillem
}

Nota: Este artículo se ha redactado en género fluido no binario, lo que quiere decir que se ha hecho uso de la letra " $x$ " o el artículo "le" para no incluir únicamente el femenino o elmasculino. La RAE no acepta este modo de escribir, pero teniendo en cuenta que es una institución reguladora con limitaciones de aceptación social, la autora del artículo asume toda responsabilidad sobre el uso del género fluido no binario y prefiere referirse a fuentes inclusivas.

Note: This paper has been written in non-binary fluid gender.

Resumen: Durante más de una década la investigadora de este artículo ha colaborado y participado activamente en la creación de estrategias de conservación y concienciación relacionadas dentro de la comunidad de artistas y profesionales del arte emergentes y de media carrera. La idea de conservación preventiva activa surge de ese trabajo. Gracias a la investigación que culminó en una tesis doctoral, se analizó y adaptó la metodología para obtener información e interaccionar con Ixs artistas, principalmente a través del uso de entrevistas, comunicaciones informales y charlas de concienciación. En este artículo se presentan los resultados de seguimiento obtenidos a través de una encuesta realizada recientemente y se plantea la posibilidad de una manera de entender la conservación preventiva como "activa" al involucrar la concienciación de lxs artistas y los beneficios que de ello se deriva, no solo para la disciplina de conservación sino para toda la comunidad artística.

Palabras clave: conservación preventiva activa, artistas emergentes, artistas de media carrera, concienciación, sinergias

\section{Active Preventive Conservation. The creation of strategies of prevention through direct work with the artists}

Abstract: For more than a decade, the researcher of this paper has collaborated and actively participated in creating awareness and conservation strategies within the community of what is referred to as emerging and mid-career artists and art professionals. The idea of active preventive conservation stems from that work. Through research that culminated in a Ph.D. thesis, the methodology for obtaining information and interacting with artists was analyzed and adapted, primarily through the artist interview, informal communications, and awareness talks. This article presents the follow-up results obtained through a recent survey and raises the possibility of a way of understanding preventive conservation as "active" by involving the awareness of artists and the benefits derived from it, not only for the conservation discipline but for the entire artistic community.

Keywords: active preventive conservation, emerging artists, mid-career artists, awareness, synergies

\section{Introducción}

Conserving doesn't mean looking back, ever. It always means looking ahead (Andrea Lissoni, Tate).

Las propuestas e ideas que se presentan en este artículo se inspiran en el trabajo llevado a cabo a lo largo de una década, desde 2011. Parte de esta experiencia es fruto de la investigación de doctorado que se defendió en 2017 la cual se centró en el uso de la entrevista como herramienta

\section{Introduction}

Conserving doesn't mean looking back, ever. It always means looking ahead (Andrea Lissoni, Tate).

The proposals and ideas presented in this article are inspired by the work carried out over a decade since 2011. Part of this experience is the outreach of the Ph.D. research that was defended in 2017, which focused on using the artist interview as a tool of prevention 
de trabajo la conservación preventiva de obras de arte realizadas por artistas emergentes que eran parte del proyecto Perspectives ${ }^{[1]}$. El resto de la información es el resultado de la práctica profesional como conservadora independiente, la asistencia e impartición de conferencias y la extensa bibliografía consultada a lo largo de ese camino; al igual que gracias a las charlas y comunicaciones personales con artistas y profesionales del arte. Se trata de la exposición de lo observado y contrastado con profesionales de disciplinas artísticas. Se ha considerado la experiencia como primera fuente de justificación, siendo ésta una fuente de aprendizaje y a la vez de inspiración para la comunidad artística en muchos otros casos. Todo ello en la línea de lo que introduce el acercamiento biográfico (biographical approach) concepto introducido en la disciplina de conservación por Renee van de Vall et al. (2011). Donde se tiene en cuenta la primera persona, lo subjetivo, como un valor añadido e imprescindible en las perspectivas de toma de decisiones y estrategias de conservación de arte contemporáneo. Son corrientes recientes en el campo de la conservación de arte contemporáneo representadas por profesionales como van Saaze (2009, 2013), van de Vall (2015), Stigter (2016), Quabeck (2021), entre otrxs que argumentan de forma convincente que la reflexión sobre las opciones y dilemas personales a los que se enfrentan Ixs profesionales complementan la investigación sobre la conservación. Así pues, en adelante, este artículo será escrito desde el punto de vista de la primera persona ya que ha sido extraído de los dilemas que han surgido en la relación directa con artistas y su interpretación subjetiva como profesional de la conservación.

Para llegar a este punto en la experiencia laboral, se ha pasado por todo un proceso de aprendizaje, identificación de errores y momentos de reflexión partiendo de una base de conservación tradicional. Al igual que a través de los errores Ixs conservadorxs han aprendido a no abusar de los disolventes, de los adhesivos y de las limpiezas agresivas, las personas que activamente contribuyen al desarrollo de una disciplina más inclusiva, holística, colaborativa y crítica se arriesgan a cometer errores y a exponerse de una manera vulnerable. Puede que lo que a continuación se expone levante alguna ceja. Esa es la idea, provocar el pensamiento crítico y cuestionar lo preestablecido a la vez de contribuir mostrando otras maneras de entender la conservación preventiva donde la figura de le artista es el eje central. El artículo muestra los resultados obtenidos tras realizar una encuesta para corroborar lo sospechado sobre la idea de conservación preventiva gracias al trabajo realizado directamente con Ixs artistas y plantea la idea de introducir esta interacción como otra manera de conservación preventiva. Se plantea el término de conservación preventiva activa, porque incluye la participación de no solo conservadxr sino también del artista y en algunos casos otrxs profesionales del arte.

\section{Contexto}

Una gran parte de profesionales en la disciplina de conservación se formaron desde la perspectiva de que while working with artworks produced by emerging artists who were part of the Perspective ${ }^{[1]}$ project. The rest of the information is the result of professional practice as an independent conservator, attending and giving conferences, and the use of a vast bibliography consulted along the way, as well as conversations and personal communications with artists and artrelated professionals. It is the exposure of what has been observed and contrasted with professionals from different disciplines. The experience has been considered as the primary source of inspiration, being it the source of knowledge and at the same time a source of inspiration to the artistic community in many other cases. All this is in line with the biographical approach, a concept introduced in the conservation discipline by Renee van de Vall et al. (2011). The first person, the subjective, is considered an added and essential value in the perspectives of decision-making and conservation strategies of contemporary art. These are recent currents in the field of contemporary art conservation represented by practitioners such as van Saaze (2009, 2013), van de Vall (2015), Stigter (2016), Quabeck (2021), among others who argue convincingly that reflection on the personal choices and dilemmas faced by practitioners complement conservation research. Thus, henceforth, this article will be written from the first-person point of view. It has been drawn from the dilemmas that have arisen in direct engagement with artists and their subjective interpretation as conservation professionals.

To get to this point in the work experience, a whole process of learning, identifying mistakes and moments of reflection has taken place from a traditional conservation base. Just as through mistakes, conservators have learned not to overuse solvents, adhesives, and aggressive cleaning methods. Those who actively contribute to developing a more inclusive, holistic, collaborative, and critical discipline risk making mistakes and exposing themselves in a vulnerable way. The following may raise some eyebrows. That is the idea to provoke critical thinking and question the pre-established while contributing to show other ways of understanding preventive conservation where the artist's figure is the central axis. The article shows the results obtained after surveying to corroborate the suspicions about the idea of preventive conservation thanks to work done directly with the artists and raises the idea of introducing this interaction as another way of preventive conservation. The term active preventive conservation is proposed because it includes the participation of the conservator and the artist and, in some cases, other art professionals.

\section{Context}

Many professionals in the conservation discipline were trained from the perspective that they would be working 
iban a trabajar en unas condiciones ideales, en grandes instituciones con ilimitados recursos y equipos de expertos, se les hizo creer que estarían en un entorno de respeto y profesionalidad manipulando piezas maestras. No obstante, la realidad es muy diferente, ya que son muy pocas las historias que coinciden con esas expectativas. Esto no significa que el resto de conservadorxs en activo en otros entornos no hagan un trabajo excelente, ético, admirable, crítico y sobre todo imprescindible, simplemente esas historias no son portadas de las grandes publicaciones científicas o divulgativas al igual que los objetos de su trabajo. Por todo ello, es necesario además de presentar el perfil de quien expone este trabajo, delimitar el perfil del objeto de estudio. Así pues, el marco en el que se encuentra este ensayo se limita a artistas y profesionales que no se encuentran representadxs por instituciones (museos, grandes colecciones, centros culturales o academia), sino a la intrincada red de lo invisible o poco visible. Es también esencial destacar o aclarar que el trabajo realizado por conservadorxs en práctica privada puede ser muy diferente al realizado por Ixs que se mueven en el mundo de las instituciones y academia y ese es el contexto desde el que se escribe este artículo, desde la visión outsider.

Las personas que inspiraron este trabajo son artistas que se pueden englobar bajo los términos de artistas emergentes y artistas de media carrera. Encontrar una definición para estos dos términos es muy complejo. No es una definición cerrada o estática. El primer problema con la denominación del término artista emergente es el asociado a la edad. Muchos concursos, llamamientos, premios y oportunidades para artistas emergentes definen un marco de edad situado entre menores de 30 o 35 $5^{[2]}$. Así, en esta definición de artista emergente no se incluye a esa persona que ha iniciado su carrera artística después de los treinta o treinta y cinco años, aunque sea un trabajo de inicio, búsqueda y, en ocasiones, no expuesto, parte de lo que se considera que define un/e artista emergente. Por todo ello, no se le considera artista emergente en el marco de ese tipo de oportunidades del entorno artístico. En otras ocasiones se define el término emergente por la cantidad de años que lleva dedicándose a la actividad artística de manera profesional. En este caso, el definido por los años en el mundo profesional, suele haber un margen entre 3 y 5 años máximo de dedicación profesional (Ontario Arts Council, Grants 2021). También está el hecho de la formación. En algunos sitios se define emergente a aquel artista recientemente graduado -normalmente menos de 5 años posteriores a finalizar la formación. En cualquier caso, aquí se referirá a emergente como alguien que emerge.

Emerger, según su definición en el diccionario de la R.A.E. es: brotar, salir a la superficie del agua u otro líquido. Emerger en sentido figurativo se define como nacer, salir de una cosa; como asomarse, aparecer alguna persona o cosa de algún lugar y también para todo aquello que empieza a dar señales de un renacimiento. Aquí se utilizará la definición que se decidió para la tesis doctoral citada anteriormente: Ixs artistas a lxs que se refiere como artistas emergentes son aquellxs que están empezando a crear profesionalmente, no tienen una in ideal conditions. In large institutions with unlimited resources and expert teams, they were led to believe that they would be in an environment of respect and professionalism handling masterpieces. However, the reality is very different, as very few stories match those expectations. This does not mean that the rest of the conservators working in other environments do not do an excellent, ethical, admirable, critical and above all essential job. It is simply that these stories do not make the front pages of the significant scientific or informative publications and the objects of their work. For all these reasons, it is necessary not only to present the profile of the person who presents this work but to delimit the profile of the object of study. Thus, the framework of this essay is limited to artists and professionals who are not represented by institutions (museums, extensive collections, cultural centers, or academia) but by the intricate network of the invisible or not very visible. It is also essential to highlight or clarify that the work done by conservators in private practice can be very different from that done by those who move in the world of institutions and academia, and that is the context from which this article is written, from the outsider's point of view.

The people who inspired this work are artists who can be encompassed by emerging artists and mid-career artists. Finding a definition for these two terms is very complex. It is not a closed or static definition. The first problem with naming the term emerging artist is that associated with age. Many competitions, calls, awards, and opportunities for emerging artists define an age range between under 30 or $35^{[2]}$. Thus, this definition of the emerging artist does not include that person who has started their artistic career after thirty or thirty-five, even if it is a starting, searching and sometimes unexhibited work, part of what is considered to define an emerging artist. For all these reasons, they are not considered an emerging artist within the framework of this type of opportunity in the artistic environment. On other occasions, the term emerging artist is defined by the number of years they have been professionally engaged in artistic activity. In this case, defined by years in the professional world, there is usually a range between 3 and 5 years maximum of professional dedication (Ontario Arts Council, Grants 2021). There is also the fact of training. In some places, emerging is defined as an artist who has recently graduated -usually less than five years after completing training. In any case, emerging will be referred to here as someone who emerges.

According to its definition in the dictionary of the R.A.E., to emerge is to sprout, to come to the surface of water or other liquid. In a figurative sense, emerge is defined as "to be born, to come out of a thing; as to show up, to appear some person or thing from somewhere and also for everything that begins to show signs of a rebirth." Here, we will use the definition that was decided for the doctoral thesis cited above: "the artists referred to as emerging artists are those who are beginning to create professionally, they 
trayectoria larga porque están empezando a dar señales de renacimiento (del Fresno-Guillem 2017: 149).

Por otra parte, para el término artistas de media carrera, son aquellxs que siguen trabajando en un entorno profesional, pero aún no han llegado a ser reconocidxs por el gran mercado o a nivel global. Aquí se utiliza la definición que presenta el Ontario Art Council para determinar quién puede optar a las ayudas bajo la categoría de artistas de media carrera:

"Mid-career: artists whose professional careers have passed the early stages, who have produced a reasonable body of work and have attained a fair degree of public exposure. You must have been practicing professionally for at least 8 years (meaning public presentation of your work) to apply to this category" (OAC, 2021).

\section{Conservación preventiva "activa", CPA, ¿a qué se refie- re?}

No hay ninguna duda a estas alturas de que la práctica y el estudio de la conservación preventiva es esencial. Tanto conservadorxs como coleccionistas o profesionales del arte tienen alguna idea de que la conservación preventiva ${ }^{[3]}$ es importante, esencial y altamente recomendable para lo que se entiende como perpetuación del patrimonio cultural. Todos estos conceptos son generalmente aceptados sobre todo cuando se habla de arte tradicional o patrimonio cultural. Entre las prácticas tradicionalmente conocidas como preventivas se han incluido las de control ambiental, de transporte y embalaje, seguridad, documentación, etc. Pero no parece que ninguna de ellas incluya la participación directa de le artista. A lo largo de más de diez años, he trabajado al lado de artistas emergentes y de media carrera y eso me ha permitido observar resultados comunes que me llevan al atrevimiento de afirmar que existe una forma de conservación preventiva que denomino conservación preventiva activa, CPA. Este término se introduce en varios puntos y en las conclusiones de mi tesis doctoral, la cual defendí en 2017:

"conseguir que el artista, en su reflexión sobre conservación, llegue a definir su propia idea o concepto de deterioro promueve una actitud de prevención, es decir, se dan las circunstancias para la conservación preventiva "activa." (del Fresno-Guillem 2017: 543)

Está extensamente probado e investigado que la perspectiva de le artista en la conservación de su obra es esencial y debe tenerse en cuenta, o por lo menos evaluarla en el momento de crear las tan amadas estrategias y protocolos de conservación. Desde los años noventa se ha introducido la práctica de la entrevista al artista (INNCA y ADP por Carol Mancusi-Ungaro) que se ha vuelto cada vez más generalizada entre instituciones y colecciones privadas; se ha hablado en torno a su eficacia y eficiencia de manera extensa a nivel internacional, con publicaciones específicas sobre metodologías relacionadas con el uso de la entrevista (como el manual publicado en 2012. Beerkens et al. 2012). do not have a long trajectory because they are beginning to show signs of rebirth" (del Fresno-Guillem 2017: 149).

On the other hand, the term mid-career artists are those who continue to work in a professional environment but have not yet become recognized by the mainstream or global market. Here we use the definition presented by the Ontario Art Council to determine who is eligible for grants under the category of mid-career artists:

\begin{abstract}
"Mid-career: artists whose professional careers have passed the early stages, who have produced a reasonable body of work and have attained a fair degree of public exposure. You must have been practicing professionally for at least 8 years (meaning public presentation of your work) to apply to this category" (OAC, 2021).
\end{abstract}

\section{"Active" Preventive Conservation, "APC", What does this mean?}

There is no doubt at this point that the practice and study of preventive conservation are essential. Conservators, collectors, and art professionals all believe that preventive conservation ${ }^{[3]}$ is important, essential and highly recommended for what is understood as the perpetuation of cultural heritage. All these concepts are generally accepted, especially when talking about traditional art or cultural heritage. Among the practices traditionally known as preventive have been those of environmental control, transport and packaging, security, documentation, and more. However, none of them seem to include the direct participation of the artist. For more than ten years, I have worked alongside emerging and mid-career artists. This has allowed me to observe common results that lead me to the audacity to affirm that there is a form of preventive conservation that I call active preventive conservation, APC. This term is introduced at several points and in the conclusions of my doctoral thesis, which I defended in 2017:

"Getting the artist, their reflection on conservation, to come to define their own idea or concept of deterioration promotes an attitude of prevention, i.e., the circumstances for "active" preventive conservation are in place." (del Fresno-Guillem 2017: 543)

It has been extensively tested and researched that the artist's perspective on the conservation of their work is essential and must be considered, or at least evaluated when creating the much-loved conservation strategies and protocols. Since the 1990s, the practice of interviewing the artist (INNCA and ADP by Carol Mancusi-Ungaro) has been introduced and has become increasingly widespread among institutions and private collections. Its effectiveness and efficiency have been discussed extensively at an international level, with specific publications on methodologies related to the use of the interview (such as the manual published 
Existen organizaciones que centran su trabajo en la voz del artista (como VoCA, Voices of Contemporary Art), hay tesis doctorales (comola anteriormente citada) o capítulos de tesis (Wielocha 2021: 37) y proyectos a largo plazo que ilustran los beneficios de esta "herramienta" como los conducidos por la fundación Getty The Artist Dialogues series (Rivenc, van Basten y Learner 2017), cursos de formación continuada (como los workshops que imparte VoCA dos veces al año o artículos que tratan el tema (Wielocha 2018). También hay detractores o, mejor dicho, críticos de la entrevista como se puede ver en el trabajo de Fernando Domínguez Rubio (2020: 120). Sin embargo, en todo este proceso de trabajo con la entrevista, o de resaltar la voz de le artista, se tiene menos en cuenta el papel que juega la concienciación y las relaciones de largo recorrido. Es por ello por lo que en este artículo se defiende que se debe trabajar directamente con Ixs artistas, no solo cuando necesitamos reunir información técnica, sino de una manera colaborativa de dos direcciones ya que enriquece todas las posibilidades. No se trata solo de conseguir información o recopilar técnicas y materiales. La entrevista, o las comunicaciones (in)formales, son también una cuestión de cuidado, y esto nutre la práctica de la conservación, y la lleva a un nuevo nivel de comprensión y colaboración.

Un extenso número de conservadorxs y/o profesionales de las artes investigan a un alto nivel técnico, de colaboración académica y resultados medibles; algo imprescindible para la comprensión de los materiales y para el desarrollo de un trabajo ético y bien informado. Esta profesionalización se suele aplicar en instituciones y academia, pero no suele contar directamente con el estudio del trabajo de artistas emergentes o de media carrera. En cambio, el mundo del arte está lleno de artistas emergentes y de media carrera con muy bajo (o ninguno) contacto con la idea de conservación preventiva o conservación en general[ ${ }^{[4]}$. A pesar de ello, es justo reconocer que existen algunas colaboraciones o investigaciones que trabajan con artistas emergentes, hay proyectos que creen en una colaboración temprana y por ese motivo, cada vez más, se incluyen nociones de conservación en centros de formación de artistas. Por poner algún ejemplo, en la Universidad de Victoria, en Australia, la Dra. Lisa Cianci desarrolló una unidad docente llamada Context and Culture donde iniciaba a sus alumnxs en los conceptos de documentación y conservación. Ya en la exégesis de su tesis doctoral señala:

"Propongo que Ixs artistas se beneficien de la incorporación consciente de estrategias de preservación en nuestras propias prácticas artísticas de una manera que nos resulte inmediatamente útil (para crear nuevas obras, para conectar con otrxs artistas y para atraer al público) y que tenga valor en el futuro para lxs posibles interesadxs.

Además, también propongo que la formación de lxs artistas en materia de conservación de soportes variables sea valiosa para nuestro campo de práctica, con el fin de capacitar a Ixs artistas para elegir las estrategias y los sistemas adecuados cuando se pongan a su disposición" (Cianci 2012). in 2012. Beerkens et al. 2012). There are organizations that focus their work on the voice of the artist (such as VoCA, Voices of Contemporary Art), there are doctoral thesis (such as the one cited above) or thesis chapters (Wielocha 2021: 37) and long-term projects that illustrate the benefits of this "tool" such as those conducted by the Getty foundation The Artist Dialogues series (Rivenc, van Basten and Learner 2017), continuing education courses (such as the workshops conducted by VoCA twice a year, or articles dealing with the topic (Wielocha 2018). There are also detractors or, rather, critics of the interview, as can be seen in the work of Fernando Domínguez Rubio (2020: 120). However, in all this process of working with the interview or highlighting the artist's voice, the role played by awareness and long-standing relationships is less taken into account. Therefore this article stands up for working directly with artists, not only when we need to gather technical information but in a twoway collaborative way that enriches all possibilities. It is not only about getting information or collecting techniques and materials. The interview, or (in)formal communications, is also a matter of care, and this nurtures the practice of conservation and takes it to a new level of understanding and collaboration.

Many conservators and/or arts professionals conduct research at a high level of technical, academic collaboration and measurable results, which is essential for understanding the materials and developing ethical and well-informed work. This professionalization is often applied in institutions and academia but does not usually include directly studying emerging or mid-career artists' work. Instead, the art world is full of emerging and mid-career artists with minimal (or no) contact with the idea of preventive conservation or conservation in general ${ }^{[4]}$. Despite this, it is fair to acknowledge that there are some collaborations or research that work with emerging artists. Some projects believe in early collaboration, and for that reason, increasingly, notions of conservation are included in artist training centers. For instance, at the University of Victoria in Australia, Dr. Lisa Cianci developed a teaching unit called Context and Culture. She introduced her students to the concepts of documentation and conservation. Already in the exegesis of her doctoral thesis, she points out:

"I propose that artists may benefit from consciously incorporating preservation strategies into our own art practices in a way that is immediately useful to us (useful in creating new work, in connecting with other artists and engaging an audience) and has value in the future to potential stakeholders.

Furthermore, I also propose that artist education in preservation of variable media is of value to our field of practice - in order to empower artists to choose suitable strategies and systems if they are made available." (Cianci 2012). 
Otrxs profesionales tratan de implementar esa concienciación y conocimientos de manera transversal en los estudios de Bellas Artes como Lúcia Almeida Matos de la Faculdade de Belas Arte (Universidade do Porto). Todxs ellxs con intención de crear un cierto conocimiento en el entorno artístico sobre las posibilidades que la conservación puede aportar. Aun así, no parece que se encuentren datos sobre los efectos que produce en la práctica del artista; incluso la propuesta anteriormente citada reconoce no saber cómo la unidad docente afecta realmente en el futuro de la práctica artística de Ixs artistas emergentes que formaron parte de ella (Cianci 2017: 227).

Así, la idea de concienciar a artistas emergentes y de media carrera en cuestiones relacionadas con conservación no es nueva, pero sí se puede arriesgar a decir que valorar las consecuencias en materia de conservación preventiva es algo que sigue estando en el horizonte y con este artículo se espera iluminar algunas posibilidades. La aportación, en este caso, es el desarrollo de una manera de hacer con el objetivo de generar conciencia como estrategia de conservación preventiva. Por lo tanto, se definiría conservación preventiva "activa" como esa que deriva de la interacción directa con artistas con intención de crear consciencia y conducirles hacia una reflexión sobre sus prácticas artísticas. Estas reflexiones pueden llevar a tomar acciones que deriven en resultados directos sobre la conservación de sus obras. Una reflexión flexible, guiada y consciente, donde se aprende de manera conjunta (artista-conservadxr) creando sinergias a partir de la concienciación y la pregunta.

En el camino de este trabajo no todo han sido resultados brillantes o metodologías infalibles, se cometieron errores que dieron lugar a cambios de dirección y a momentos de autorreflexión y autocrítica. Todo ello ha contribuido a un proceso de aprendizaje, pero no se puede afirmar que se tengan todas las respuestas, ya que es un proceso continuo de aprendizaje. Lo que se puede afirmar es que Ixs artistas que han tenido la oportunidad de entrar en contacto con conceptos relacionados con conservación, han podido hablar y reflexionar sobre ciertas ideas con una o varias personas profesionales de la conservación, han tenido la posibilidad de decidir y ser conscientes de algunos aspectos particulares de su trabajo y eso les ha ayudado en la toma de decisiones. Cuando hablamos de ayuda no es desde una perspectiva paternalista de conducir y corregir sino a través de una conversación abierta y llena de reflexión, como facilitadorxs. Por lo tanto, Ixs artistas se encuentran en una posición donde se les brinda la oportunidad de reflexionar y analizar conceptos como envejecimiento, cambio, materiales, autenticidad, instalación o documentación; Ixs conservadorxs pueden, a su vez, aprender sobre el proceso creativo, acercamientos, o perspectivas que enriquecerán su conocimiento ético. Se crean diálogos abiertos donde a través de la entrevista el/la artista o la conversación abierta, se pueden establecer nuevas perspectivas y estrategias de conservación preventiva conjuntamente.
Other professionals try to implement conservation awareness and knowledge transversally in Fine Arts studies, such as Lúcia Almeida Matos does at the Facultade de Belas Arte (Universidade do Porto). All of them create a certain knowledge in the artistic environment about the possibilities that conservation can bring. No data seems to be found on the effects it produces on the artist's practice; even the proposal mentioned above acknowledges not knowing how the teaching unit affects the future artistic practice of the emerging artists who took part in it (Cianci 2017: 227).

Thus, the idea of making emerging and mid-career artists aware of conservation issues is not new. However, one can venture to say that assessing the implications for preventive conservation is still on the horizon, and this article hopes to illuminate some possibilities. The contribution, in this case, is the development of a way of doing to generate awareness as a preventive conservation strategy. Therefore, "active" preventive conservation would be defined as that which derives from direct interaction with artists intending to create awareness and lead them to reflect on their artistic practices. These reflections can lead to actions that derive results directly on the conservation of their works. A flexible, guided and conscious reflection, where we learn together (artistconservator), creating synergies from awareness and questioning.

In the course of this work, not everything has been brilliant results or infallible methodologies; mistakes were made that led to changes in direction and moments of self-reflection and self-criticism. All this has contributed to a learning process, but it cannot be said that we have all the answers since it is a continuous learning process. What can be said is that the artists who have had the opportunity to come into contact with concepts related to conservation have been able to talk and reflect on specific ideas with one or more conservation professionals, have had the possibility to decide and be aware of some particular aspects of their work and that has helped them in making decisions. When we talk about help, it is not from a paternalistic perspective of driving and correcting but through an open and reflective conversation as facilitators. Thus, artists are in a position where they are given the opportunity to reflect on and analyze concepts such as ageing, change, materials, authenticity, installation, or documentation; conservators can, in turn, learn about the creative process, approaches, or perspectives that will enrich their ethical knowledge. Open dialogues are created where new perspectives and preventive conservation strategies can be jointly established through the artist interview or open conversation.

\section{Datos}

\section{Data}

Antes de pasar a exponer tres casos prácticos que pueden

Before presenting the three case studies that will help 
ayudar a ilustrar lo anteriormente mencionado, sería necesario presentar una serie de datos cuantitativos. Éstos fueron obtenidos con una encuesta de seguimiento entre algunxs de Ixs artistas con los que se ha trabajado a lo largo de esta década. La encuesta se lanzó a 50 de Ixs artistas que han estado de alguna forma en contacto con la idea de conservación a través de entrevistas, comunicaciones, formación y otros eventos. Se escogió mandar la encuesta a artistas con prácticas variadas, de diferentes partes del mundo, de diferentes rangos de edad y que han tenido más de un contacto esporádico conmigo. La encuesta se utilizó para corroborar los datos que se intuían en la práctica. Para ello, se realizó un sencillo formulario en google docs con una serie de cuestiones relacionadas con conservación y cómo ésta había afectado a su trabajo. Este cuestionario constaba de la siguiente estructura: una sección de identificación de le artista, su(s) área(s) de trabajo y el consentimiento necesario para el uso de los datos; seguida de 12 preguntas cortas o de respuesta booleana (sí, no, otros). Contestaron al cuestionario un total de 44 artistas de los 50 consultados. Artistas de diferentes nacionalidades (España, Canadá, Brasil, Israel, Chile, Perú, Francia, Italia, Siria, Países Bajos, Venezuela y Estados Unidos). Las preguntas del cuestionario eran variadas, centradas en cuándo se tomó conciencia sobre conservación, cómo la conciencia sobre conservación había afectado a su trabajo (si es que ha afectado) y si había cambiado algo en su práctica. [Figura 1] illustrate the above, it would be necessary to present a series of quantitative data. These were obtained from a follow-up survey among some of the artists I have worked with throughout this decade. The survey was sent to 50 of the artists who have been in some way in contact with the idea of conservation through interviews, communications, training, and other events. Artists with varied practices, from different parts of the world, of different age ranges and who have had more than sporadic contact with me were chosen to be surveyed. The survey was used to corroborate the data that was intuited from the practice. For that reason, a simple form was made in google docs with a series of questions related to conservation and how it had affected their work. This questionnaire consisted of the following structure: a section identifying the artist, their area(s) of work and the necessary consent to use the data, followed by 12 short or Boolean response questions (yes, no, other). A total of 44 artists out of the 50 answered the questionnaire. Artists of different nationalities -Spain, Canada, Brazil, Israel, Chile, Peru, France, Italy, Syria, the Netherlands, Venezuela, and the United States. The questions were varied, focusing on when they became aware of conservation, how conservation awareness had affected their work (if at all), and whether it had changed anything in their practice. [Figure 1]

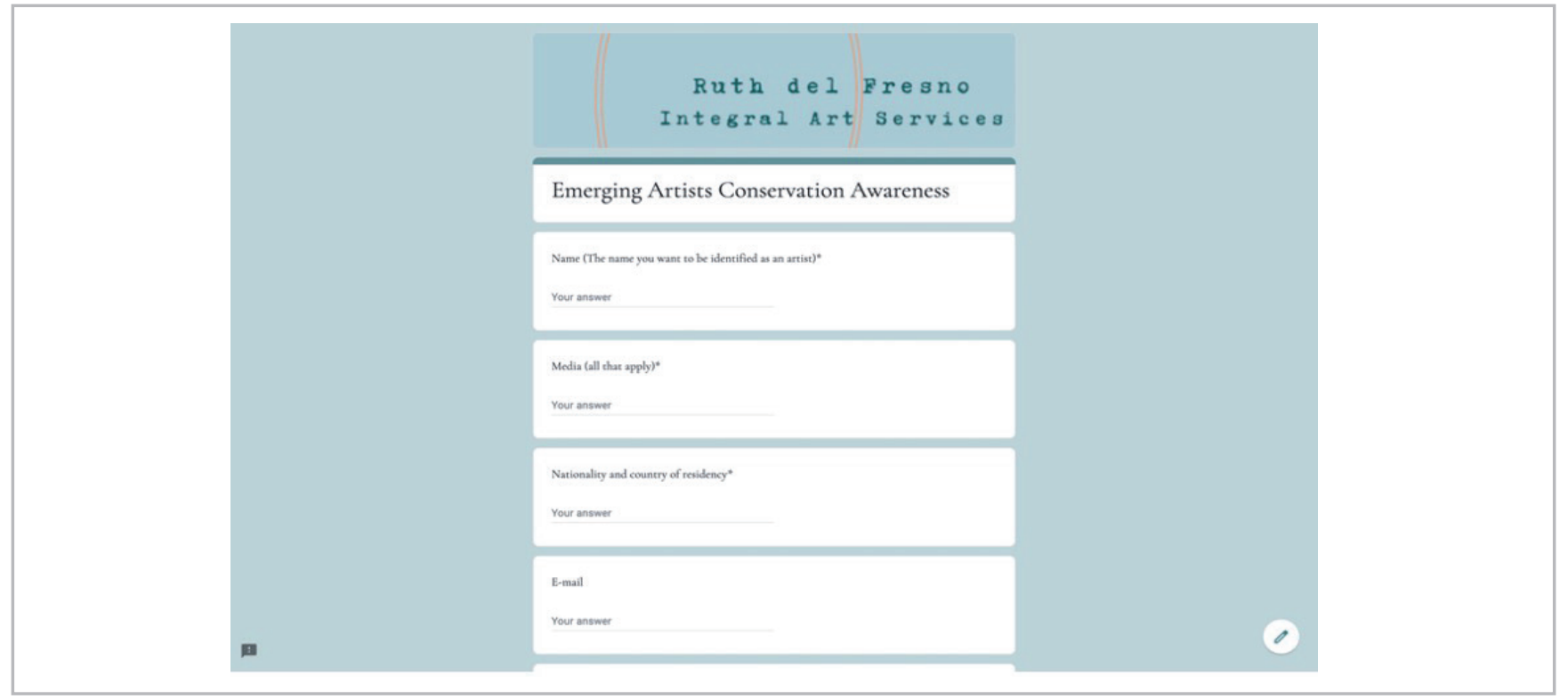

Figura/Figure 1.- Cuestionario en Google Forms enviado a Ixs artistas. Captura de pantalla. / Screenshot of the Google docs questionnaire sent to the artists.

Con los datos obtenidos se desveló que en este grupo de artistas el $80 \%$ entró en contacto con la idea de conservación a raíz de la entrevista que se les hizo cuando formaron parte de la investigación del proyecto Perspectives (2013-2016). El 20\% restante mostró una multitud de respuestas tales como: "supe sobre conservación durante mis estudios", "en una visita guiada de un museo", "a través de un compañero", "por un documental", "a través de un accidente con una de mis obras", entre otras.
With the data obtained, it was revealed that in this group of artists, $80 \%$ encountered the idea of conservation due to the interview they were given when they were part of the Perspectives project research (2013-2016). The remaining $20 \%$ showed a multitude of answers such as: "I learned about conservation during my studies," "on a guided tour of a museum," "through a colleague," "through a documentary," "through an accident with one of my works," among others. 
Se les preguntó si previamente a este contacto les preocupaba la conservación, la durabilidad y los cambios en su obra. Curiosamente los porcentajes son similares: el $54.5 \%$ no se preocupaba de conservación antes de entender de qué se trataba y al $47.7 \%$ no les preocupaba ni la durabilidad ni el cambio. Sorprendentemente el $72.7 \%$ afirma que tras ese contacto empezaron a tomar medidas en relación con la conservación de su obra, aunque sigue existiendo un $20.5 \%$ que taxativamente contestan que no han cambiado nada después de hacerse conscientes. El resto, está repartido en respuestas más variadas y menos tajantes:"depende del proyecto", "lo intento" o"no estoy segura". Posteriormente, una pregunta que resaltaba especialmente era la relacionada con el proceso creativo. Se les cuestionó si ser conscientes sobre temas relacionados con conservación les había influenciado en su proceso creativo y en este caso el $41.9 \%$ contestó un no rotundo, el $44.2 \%$ un sí rotundo y el resto dudaba entre diferentes situaciones, tales como: "he dejado la práctica artística", "depende del proyecto" o" no me lo he planteado."

Resultó muy gratificante descubrir que el $100 \%$ de Ixs artistas consultadxs consideraban que era muy bueno que se les informe sobre conservación y que la concienciación es un valor que aprecian, todxs se han mostrado muy agradecidxs por haber tenido la oportunidad de aprender sobre estas cuestiones y el $100 \%$ quería seguir en contacto y seguir aprendiendo sobre el tema. Lo que lleva a la conclusión de que si bien no todxs Ixs artistas, una vez conocen los conceptos básicos de conservación, aplican o implementan cambios en su práctica, ni se puede afirmar que comunicarse con Ixs artistas es una garantía para la implementación de prácticas de conservación preventiva, si es taxativa la posición de que las personas creadoras se muestran a favor de la experiencia de aprendizaje y análisis de posibilidades y, en consecuencia, de alguna manera hará que sus decisiones sean conscientes.

Desde los primeros pasos en esta experiencia trabajando con artistas emergentes y de media carrera, el objetivo principal fue concienciar, dar herramientas para decidir en conciencia. Lo que se consideró esencial, es el hecho de que si algo no se conoce no nos causa ninguna preocupación y por lo tanto no se puede decidir conscientemente. Lo que al final cada artista decida hacer no es lo más importante, sino que se considera que lo esencial es que tenga las herramientas necesarias para tomar una decisión consciente, conociendo las consecuencias que se pueden controlar ${ }^{[5]}$. Varixs artistas con Ixs que se ha trabajado a lo largo de estos diez años han decidido conscientemente dejar que su obra desaparezca sin hacer nada por evitarlo, pero lo han hecho desde la consciencia, desde el conocimiento de las consecuencias de no tomar medidas para evitar esa desaparición. Otrxs han decidido que no les interesaba preocuparse por la vida de sus obras una vez terminado su proceso creativo, que lo dejaban en manos de quien tuviese que gestionar, coleccionar o adquirir la obra. Hay que decir que esta postura no era muy común, ya que la mayoría de lxs artistas consultadxs mostraron interés por controlar lo que le sucede a su trabajo, sea en la dirección
They were asked if, before this contact, they were concerned about conservation, durability and changes in their work. Interestingly, the percentages are similar: $54.5 \%$ were not concerned about conservation before they understood what it was about, and $47.7 \%$ were not concerned about durability or change. Surprisingly, $72.7 \%$ said that they began to take measures concerning the conservation of their work after this contact. However, there are still $20.5 \%$ who categorically answered that they had not changed anything after becoming aware of it. The rest are divided into more varied and less categorical answers: "it depends on the project," "I try," or "I am not sure." Subsequently, one question that particularly stood out was related to the creative process. They were asked if being aware of conservation-related issues had influenced them in their creative process. In this case, $41.9 \%$ answered a resounding no, $44.2 \%$ a categorical yes, and the rest hesitated between different situations, such as "I have stopped the artistic practice," "it depends on the project," or "I have not considered it."

It was gratifying to discover that $100 \%$ of the artists consulted felt it crucial to be informed about conservation. That awareness is a value they appreciate. All were very grateful for having had the opportunity to learn about these issues, and $100 \%$ wanted to stay in touch and continue learning about the subject. This leads to the conclusion that -although not all artists, once they know the basic concepts of conservation, apply or implement changes in their practice, nor can it be affirmed that communicating with artists is a guarantee for the implementation of preventive conservation practice- it is clear that creators are in favor of the learning experience and analysis of possibilities and, consequently, will somehow make their decisions consciously.

From the first steps in this experience working with emerging and mid-career artists, the main objective was to raise awareness, to give tools to decide in conscience. What was considered essential is that if something is not known, it does not cause us any concern and therefore, it is not possible to decide in conscience. What each artist decides to do is not the most important thing, but what is considered essential is that they have the necessary tools to make a conscious decision, knowing the consequences that can be controlled ${ }^{[5]}$. Several artists I have worked with over the last ten years have consciously decided to let their work disappear without doing anything to prevent it. However, they have done it aware, from the knowledge of the consequences of not taking measures to prevent its disappearance. Others have decided that they were not interested in worrying about the life of their works once their creative process was over, that they would leave it in the hands of whoever had to manage, collect, or acquire the work. It must be said that this position was not very common since most of the artists consulted showed interest in controlling what happens to their work, either in the direction of perpetuating it or 
de perpetuarlo o en la opuesta. En cualquier caso, se podría creer que trabajar de una manera colaborativa desde lo más temprano en la carrera de unx artista ayuda al conservadxry a le artista a prevenir, respetar, y entender el arte producido en este siglo.

\section{Casos prácticos}

Como ya se ha indicado, este artículo se nutre del seguimiento de un grupo de artistas a lo largo de un período extendido. Algunxs de Ixs artistas han mantenido contacto regular convirtiéndose en relaciones de largo plazo y dando pie a revisiones de conceptos ya tratados. Para ilustrar las ideas que se han introducido, a continuación, se exponen tres casos de estudio, de este modo se puede ver de manera práctica diferentes situaciones en las que Ixs artistas han tomado conciencia de la conservación de su trabajo y con ello han empezado a introducir prácticas que repercuten de manera activa en la conservación preventiva de sus obras de arte.

\section{- Art al Quadrat (artistas emergentes en el momento de ini- ciar la colaboración)}

Es un grupo artístico formado por las hermanas gemelas Gema y Mònica del Rey Jordà. Desde 2013 se han mostrado muy interesadas en reflexionar sobre conservación, especialmente durante el proceso de la entrevista realizada para la conservación de su pieza Estado Crónico Ell Silvia, 2013 [Figura 2] parte del proyecto Perspectives, Art-Inflammation and $\mathrm{Me}^{[6]}$. En ese momento eran artistas emergentes. Esta obra en concreto está formada por una pieza física (realizada en madera sin tratar) y un archivo de vídeo. La emisión del vídeo debía presentarse en una pantalla con las dimensiones de la mujer representada. No se podía proyectar y se tenía que respetar las medidas y forma del monitor. Durante la entrevista para tratar de establecer los parámetros de conservación de la obra, se observó que Art al Quadrat estaban más preocupadas por la obsolescencia que pudiese sufrir el archivo que por otros aspectos de la obra. Al reflexionar sobre la importancia de los parámetros establecidos para una correcta presentación de la obra, se concluyó que la no presentación de la obra como se indicaba era el mayor deterioro que la obra podría sufrir. Esto era algo que no se habían planteado anteriormente y que les hizo tomar consciencia de la importancia de establecer las indicaciones de instalación en un documento para que no se diese ese deterioro.

A raíz de lo reflexionado en la entrevista, las artistas de Art al Quadrat implementaron ciertas prácticas relacionadas con la conservación de su obra y empezaron a incluir aspectos de conservación en la documentación que generaban a la hora de vender su trabajo. En la reflexión generada con el proceso de la investigación se mostraron especialmente interesadas en la obra con base tecnológica. Todas las implicaciones relacionadas con la obsolescencia y el paso del tiempo en este tipo de trabajos les hizo replantearse los soportes y el in the opposite direction. In any case, one could believe that working collaboratively from the earliest stages of an artist's career helps the conservator and the artist prevent, respect, and understand the art produced in this century.

\section{Cases of Study}

As already indicated, this article is nurtured by following a group of artists over an extended period of time. Some of the artists have been in regular contact, which has become a long-term relationship and has given rise to revisions of concepts already discussed. To illustrate the ideas that have been introduced, three case studies are presented below, in order to show in a practical way different situations in which artists have become aware of the conservation of their work and have begun to introduce practices that have an active impact on the preventive conservation of their works of art.

\section{-Art al Quadrat (Emerging artists when the collaboration started)}

It is an artistic group formed by the twin sisters Gema and Mònica del Rey Jordà. Since 2013 they have been very interested in reflecting on conservation, especially during the interview process conducted to conserve their piece Estado Crónico Ell Silvia, 2013 [Figure 2] part of the project Perspectives, Art-Inflammation and $\mathrm{Me}^{[6]}$. At that time, they were emerging artists. This particular work consists of a physical piece (made of untreated wood) and a video archive. The video broadcast was to be presented on a screen with the dimensions of the woman depicted. It could not be projected, and the dimensions and shape of the monitor had to be respected. During the interview to establish the parameters for the conservation of the work, it was observed that Art al Quadrat was more concerned about the obsolescence of the archive than about other aspects of the work. When reflecting on the importance of the parameters established for the correct presentation of the work, it was concluded that the failure to present the work as indicated was the most significant deterioration that the work could suffer. This was something they had not previously considered and made them aware of the importance of establishing the installation indications in a document so that this deterioration would not occur.

As a result of what was reflected in the interview, the artists of Art al Quadrat implemented certain practices related to the conservation of their work. They began to include aspects of conservation in the documentation they generated when selling their work. In the reflection generated through the research process, they were particularly interested in technology-based work. All the implications related to obsolescence and the passage of time in this work made them rethink the supports 


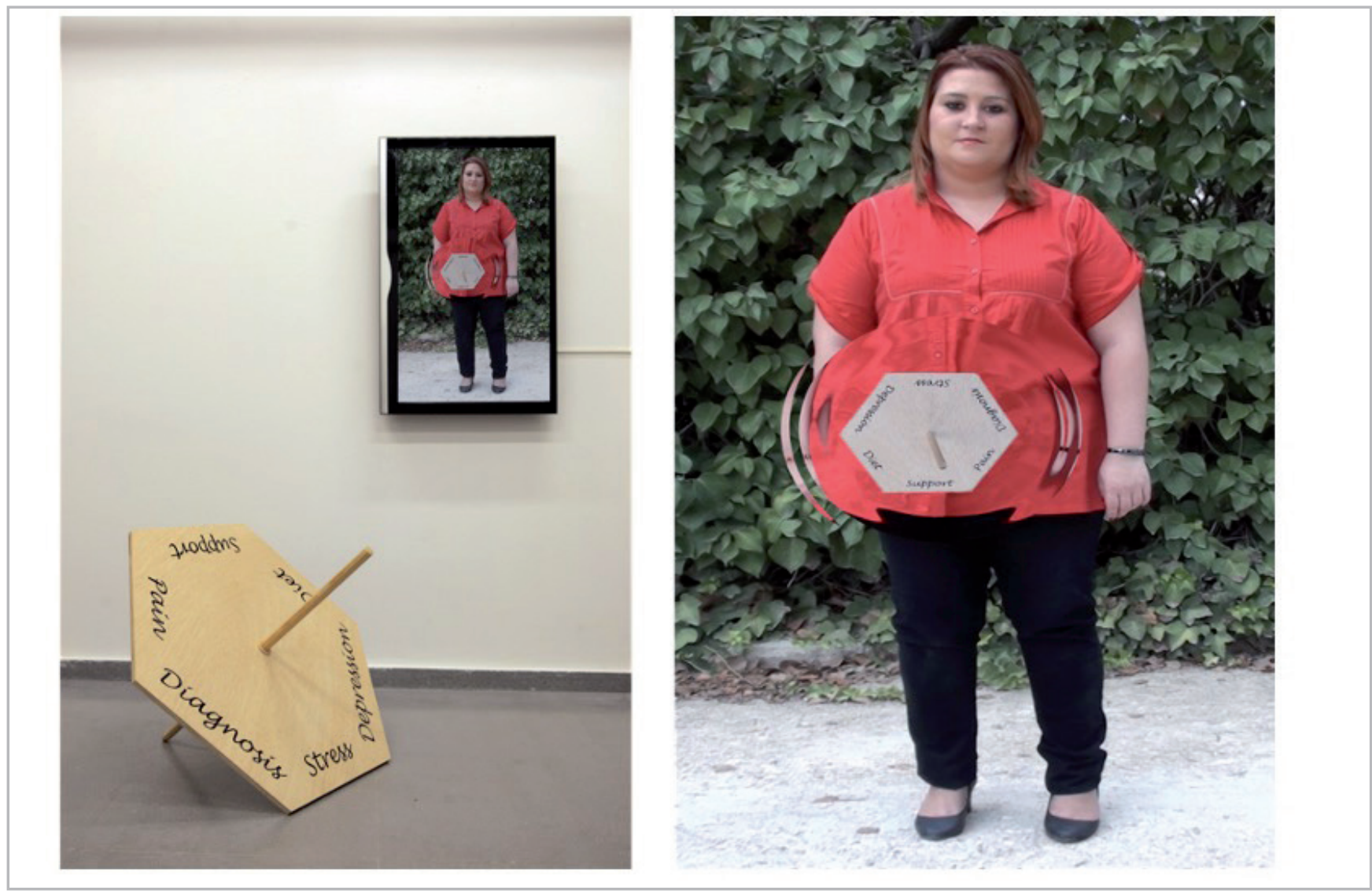

Figura/Figure 2.- Estado Crónico Ell Silvia, 2013, Art al Quadrat. Imágenes que forman parte de la documentación del proyecto Perspectives, Art-Inflammation and Me. Derechos de uso cedidos a la autora de este artículo / Estado Crónico Ell Silvia, 2013, Art al Quadrat. Images part of the documentation of the project Perspectives, Art-Inflammation and Me. Rights of use granted to the author of this article. Rights of use are granted to the author of this article.

envejecimiento visual (estético) de la obra generada en soporte vídeo. En realidad, a partir de unas charlas a las que habían asistido, se hicieron conscientes de que podían incluir una serie de anotaciones al respecto de la obsolescencia tecnológica de su obra en soporte vídeo. Se les sugirió que en un formato de contrato incluyesen una cláusula donde el comprador se debía hacer responsable ${ }^{[7]}$ de actualizar (migrar) la obra a un soporte y formato que garantice la durabilidad de la obra. Tras esto, se mantuvieron conversaciones relacionadas con prácticas de documentación, algo que ellas en su práctica artística tenían muy bien investigado ya que parte de su trabajo se nutre de archivos y memoria histórica. Pero no solo la documentación era un paso hacia las posibles estrategias de conservación sino también el hecho de reflexionar y aceptar, en algunos casos, un envejecimiento digno de la materia sin problemas por el resultado estético.

En el caso de la obra anteriormente citada [Figura 2] establecieron que la parte física de la instalación aceptaba un cierto envejecimiento que no requería de tratamiento alguno yen el caso de que esa parte de la instalación perdiese su integridad, ésta podía sustituirse o rehacerse. Este tipo de decisiones les ayudó a plantearse estrategias para sus obras futuras siendo una constante en su trabajo actual. Este tipo de reflexión conjunta ayuda al conservadxr a entender que en ocasiones la estrategia de conservación más adecuada and the visual (aesthetic) ageing of the work generated in video support. In fact, from some talks they had attended, they became aware that they could include a series of annotations regarding the technological obsolescence of their video work. It was suggested that in a contract format, they include a clause in which the buyer should be responsible ${ }^{[7]}$ for upgrading (migrating) the work to a medium and format that would guarantee the durability of the work. After this, conversations were held related to documentation practices. Their artistic practice was very well researched since part of their work is nourished by archives and historical memory. Nevertheless, the documentation was a step towards possible conservation strategies and the fact of reflecting and accepting, in some cases, dignified ageing of the material without problems for the aesthetic result.

In the case of the aforementioned work [Figure 2] they established that the physical part of the installation accepted a certain ageing that did not require any treatment and in the event that this part of the installation lost its integrity, it could be replaced or remade. This type of decision helped them to consider strategies for their future works which is a constant in their current work. This type of joint reflection helps the conservator to understand that sometimes the most appropriate 
no es la permanencia sino la aceptación ya que para Art al Quadrat, por ejemplo, no había tanto conflicto en que la parte física estuviese prístina, pero en cambio estaban muy preocupadas por que la parte tecnológica se oyese y viese con el formato y calidad adecuadas.

Al poco tiempo de realizar la entrevista para el proyecto Perspectives, se pusieron en contacto para informar de la adquisición de una de sus obras por parte de la colección de arte de la Generalitat Valenciana [Figura 3]. Esta obra tiene partes móviles, físicas, documentales. Uno de los elementos, parte de una de las versiones de la instalación, son billetes de moneda republicana auténticos. Estos billetes vuelan impulsados por unos ventiladores [Figura 3 imagen superior izquierda] algunos quedan enganchados en las aspas de los ventiladores y se destruyen. Tras haber reflexionado sobre la idea de deterioro en la entrevista, decidieron que eso no era un deterioro. Decidieron conscientemente que, aunque era algo que no se habían planteado que pudiese ocurrir, era un efecto que añadía valor a la intencionalidad de la obra y evitar su ruptura sería modificar el mensaje. En el momento de la adquisición de la obra adjuntaron una serie de documentos específicos en relación con la conservación de la obra con intención de ser parte activa en la conservación preventiva de su trabajo. conservation strategy is not permanence but acceptance, since for Art al Quadrat, for example, there was not so much conflict about the physical part being pristine, but they were very concerned about the technological part being heard and seen with the right format and quality.

Shortly after the interview for the Perspectives project, they got in touch to inform about the acquisition of one of their works by the art collection of the Generalitat Valenciana [Figure 3]. This work has moving parts, physical parts, documentary parts. One of the elements, part of one of the installation versions, is original republican currency bills. These bills are blown by fans [Figure 3 top left image]; some of them get caught in the fans' blades and are destroyed. After reflecting on the idea of deterioration in the interview, they decided that this was not deterioration. They consciously decided that, although it was something they had not considered could happen, it was an effect that added value to the work's intentionality and to avoid breaking it would be to modify the message. At the time of the acquisition of the work, they enclosed a series of specific documents concerning the conservation of the work to be an active part of the preventive conservation of their work.

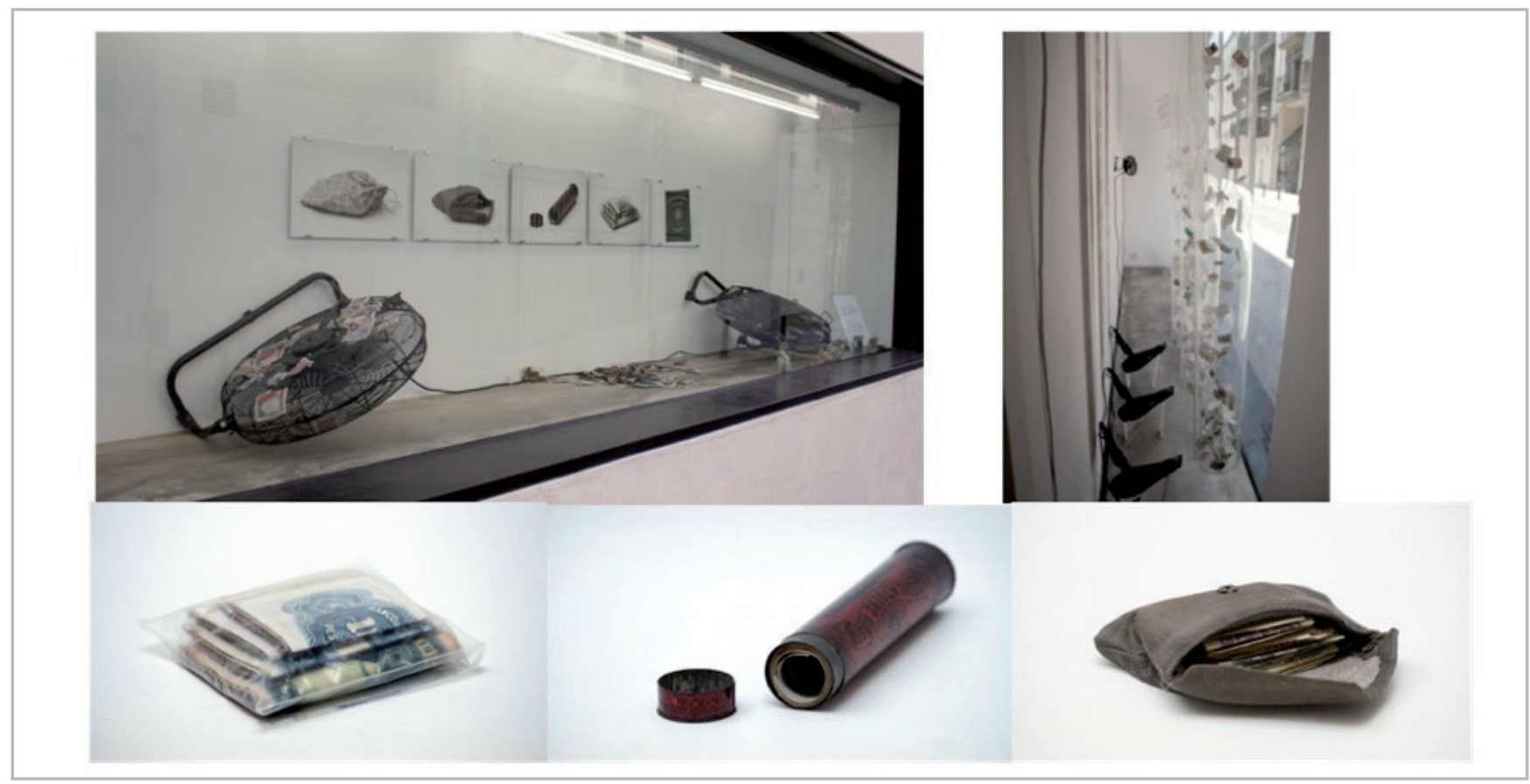

Figura/Figure 3.- ELimbo Económico en Tres Actos, 2014, Art al Quadrat. Dos Actos y tres imágenes de detalle. Imágenes propiedad de Art al Quadrat.] / Limbo Económico en Tres Actos, 2014, Art al Quadrat. Dos Actos and three detailed images. Images rights by Art al Quadrat. Rights of use are granted to the author of this article.]

\section{- Coco Guzmán (en el momento de iniciar el trabajo con elle ${ }^{[8]}$ era une artista emergente)}

El siguiente caso de estudio para ilustrar la importancia del trabajo a largo recorrido sería el caso de Coco Guzmán, artista Queer con le que se ha estado colaborando desde 2018. Coco Guzmán realiza un tipo de trabajo en soportes muy variados, pero que mayormente es dibujo. Su dibujo se
-Coco Guzmán, (They ${ }^{[8]}$, were an emerging artist when the contact for this work was initiated)

The following case study to illustrate the importance of long-term work would be the case of Coco Guzman, a Queer artist with whom we have been collaborating since 2018. Coco Guzman performs a type of work in very varied supports, but that mostly tends to draw. 
encuentra sobre papel de cualquier calidad, tamaño y forma; arquitectura (pared, suelo, loza del W.C.); formato digital e intervenciones efímeras espaciales (acciones urbanas). En los últimos 3 años, se han llevado a cabo dos entrevistas formales con Coco y múltiples conversaciones. La primera se realizó el 8 de marzo de 2019 durante la instalación de su exposición Las cosas que se quedan -The Things that Remain. La segunda se realizó el 13 de mayo de 2019 en su taller de artista justo después de su participación en la muestra colectiva Ad Infinitum comisariada por Magda GonzálezMora, en el espacio Arsenal Habana, muestra colateral de la XIII Bienal de la Habana. A parte de estas dos entrevistas formales, se ha mantenido una relación continuada que ha dado pie a colaboraciones en congresos y simposios (IPCE, noviembre 2019) donde se han discutido conceptos de conservación de una manera abierta y colaborativa. Como ya se presentó en el artículo publicado en Unicum, (del Fresno-Guillem 2020), la colaboración ha llevado a un enriquecimiento mutuo entre artista y conservadora. Por una parte, Coco ha reflexionado sobre la durabilidad de sus obras y cómo determinar lo que es deterioro en su obra y lo que no lo es. Por otra parte, la conservadora ha aprendido a incluir en sus parámetros de conservación visiones no binarias y acepciones de género en el trabajo de conservación. La concienciación sobre que se clasifica todo desde un punto de vista de género "masculino mayestático" o que se limitan las opciones a cuestiones binarias. Para le artista, ha hecho que incluya temas de conservación en su trabajo de manera que, aunque utiliza materiales que pueden ser de menor calidad en algunas de sus obras, es consciente del cambio que pueden sufrir y lo acepta y comunica a sus clientes. Con ello se realiza un trabajo de advertencia sobre que algunas de sus obras no pretenden durar para siempre o cómo debe actuarse al respecto. Son trabajos con una fecha de caducidad que se solidarizan con los conceptos de su investigación, trabajo que se soporta en archivos históricos de desaparecidxs, de memoria borrada o eliminada a propósito. Coco es consciente ahora de la utilización de materiales que benefician o soportan su intencionalidad. Su trabajo más reciente Perversidad de la Arruga, 2021 parte de la exposición colectiva Con-Tacto, comisariada por Fefa Vila [Figura 4]. Aunque este trabajo está realizado en carboncillo, gesso y papel, el material principal es el tacto, la caricia, el desgarro; se muestra como un trabajo con un formato físico (el dibujo sobre papel) instalado sobre muro y otros elementos arquitectónicos. Como le propia artista señala en el catálogo de la exposición: "El arte es un hecho háptico de materialidad..." (Guzmán 2021: 25) la caricia y el gesto "saca la pluma" al carboncillo y entender eso será primordial para que su obra se mantenga en las condiciones de su creación.

En este caso las tácticas de conservación están establecidas más en relación con la intencionalidad y en evitar la disociación de la obra. Coco es consciente de ello y toma decisiones que informa. De este modo genera consciencia sobre conservación también a las personas que tienen que gestionar o manipular su trabajo. Una vez más, la entrevista y las conversaciones mantenidas, ayudan a que le artista
Their drawing can be found on paper of any quality, size and shape; architecture (wall, floor, W.C. ceramic); digital format and ephemeral spatial interventions (urban actions). There has been the opportunity to conduct two formal interviews with Coco and multiple fluid conversations in the last three years. The first took place on March 8, 2019, during the installation of their exhibition Las cosas que se quedan -The Things that Remain. The second interview was conducted on May 13, 2019, at their artist's studio right after their participation in the group show Ad Infinitum curated by Magda González-Mora, at the Arsenal Habana space, collateral show of the XIII Havana Biennial. Apart from these two formal interviews, an ongoing fluid relationship has led to collaborations even in congresses and symposiums (IPCE, November 2019), where conservation concepts have been discussed openly and collaboratively. As presented in the article published in Unicum (del FresnoGuillem 2020), the collaboration has led to a mutual enrichment between artist and conservator. On the one hand, Coco has reflected on the durability of their works and how to determine what is deterioration in their work and what is not. On the other hand, the conservator has learned to include non-binary visions and gender meanings in conservation work in her conservation parameters. Awareness that everything is classified from a "masculine-majority" gender point of view or that options are limited to binary positions. For the artist, it has caused them to include conservation issues in their work. Although they use materials that may not be of high quality in some of their works, they are aware of the change they may undergo and accept and communicate this to their collectors. With this comes a warning that some of their works are not intended to last forever or how they should be acted upon. They are works with an expiration date that is in solidarity with the concepts of their research, supported by historical archives of missing people, of erased memory or purposely eliminated. Coco is now conscious of the use of materials that benefit or support their intentionality. Their most recent work Perversidad de la Arruga, 2021, is part of the group exhibition Con-Tacto, curated by Fefa Vila [Figure 4]. Although this work is made in charcoal, gesso and paper, the primary material is touch, caress, tearing; it is shown as a work with a physical format (drawing on paper) installed on walls and other architectural elements. As the artist theirself points out in the exhibition catalogue: "Art is a haptic fact of materiality..." (Guzmán 2021: 25) the caress and the gesture "takes the pen" out of the charcoal and understanding this will be essential for their work to remain in the conditions of its creation.

In this case, the conservation tactics are established more about intentionality and avoiding the work's dissociation. Coco is aware of this and makes decisions that inform. In this way, they also generate conservation awareness for the people who have to manage or handle their work. Once again, the interview and the conversations helped the artist define their idea of deterioration in each case 
defina su idea de deterioro en cada caso y en cada momento y esto hace que le artista se convierta en un elemento activo y proactivo en la conservación preventiva de su obra. Gracias a esa conciencia realiza pruebas de envejecimiento, cambios y durabilidad de los materiales que utiliza para poder decidir qué cambios son admisibles y cómo se deben gestionar. and at each moment, making the artist an active and proactive element in the preventive conservation of their work. Thanks to this awareness, they test the ageing, changes and durability of the materials they used in order to decide which changes are admissible and how they should be managed.

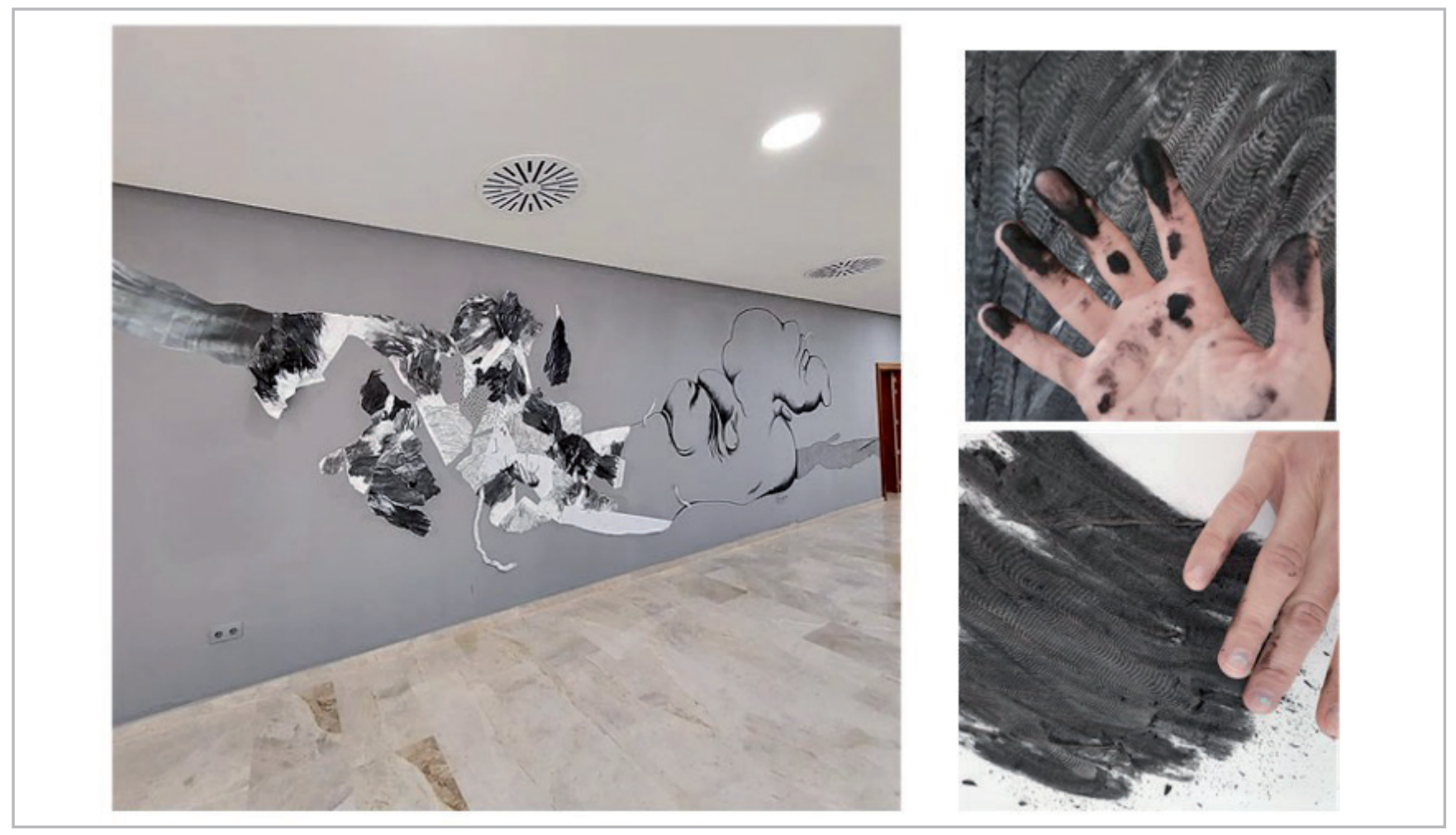

Figura/Figure 4.- Perversidad de la Arruga, 2021, Coco Guzmán. (izq.) Instalación de la obra en la exposición Con-Tacto, comisariada por Fefa Vila, UMH, Elche. (dcha.) Proceso creativo de acariciar el dibujo. Imágenes propiedad de Coco Guzmán. / Perversidad de la Arruga, 2021, Coco Guzmán. (left) Artwork installation in the exhibition Con-Tacto, curated by Fefa Vila, UMH, Elche. (right) creative process of caressing the drawing Images rights owned by Coco Guzmán. Rights of use are granted to the author of this article.

\section{- Francisco-Fernando Granados, artista de media carrera}

El tercer caso que se presenta es del artista de media carrera Francisco-Fernando Granados, artista que ha realizado gran parte de su trabajo en formato Performance Art. Granados trabaja la abstracción en formato dibujo (digital y analógico) y en ocasiones la instalación. A lo largo de su carrera docente y de producción artística ha experimentado con el uso de gran variedad de materiales y disciplinas, pero todo gira alrededor de temas vinculados con el desplazamiento (físico, entre países, en condición humana, emocional, de género), la resistencia a los protocolos de identidad (sexual, como ente administrativo, como profesional). Se han mantenido conversaciones informales con FranciscoFernando Granados desde 2018. El 15 de enero de 2021, se realizó una entrevista formal detallada para la conservación de una parte de su trabajo. Esta entrevista se realizó con el objetivo de crear una estrategia de documentación y conservación para una obra específica spatial profiling... (realizada por primera vez en 2009) [Figura 5] La primera vez que esta obra fue realizada, fue una performance en/ de proceso. La performance ha evolucionado porque el

\section{-Francisco-Fernando Granados, a mid-career artist}

The third case presented is the mid-career artist Francisco-Fernando Granados, who has done much of his work in Performance Art format. Granados works abstraction in drawing format (digital and analog) and sometimes installation. Throughout his teaching and artistic production career, he has experimented with the use of a great variety of materials and disciplines. However, everything revolves around themes linked to displacement (physical, between countries, the human condition, emotional, gender) and resistance to identity protocols (sexual, as an administrative entity, as a professional). Informal discussions have been held with Francisco-Fernando Granados since 2018. On January 15, 2021, a detailed formal interview was conducted to conserve a part of his work. This interview was conducted to create a documentation and conservation strategy for the specific work spatial profiling... (first performed in 2009) [Figure 5] The first time this work was performed, it was a performance in/of process. The performance has evolved because 
artista ha evolucionado. Se trata de un cuerpo político ${ }^{[9]}$ y en sus propias palabras: "lo importante es que se realice por cuerpos políticos, no tienen que ser yo". En el transcurso de la entrevista se reflexionó sobre la autenticidad de la obra y los cambios que se generan en cada iteración. El artista se hace consciente de la importancia que puede tener para él las diferentes versiones, pero la considera la misma obra. the artist has evolved. It is a political body ${ }^{[9]}$, and in his own words, "the important thing is that political bodies perform it, they do not have to be me." In the interview, the authenticity of the work and the changes generated in each iteration were reflected upon. The artist becomes aware of the different versions' importance for him, but he considers it the same work.
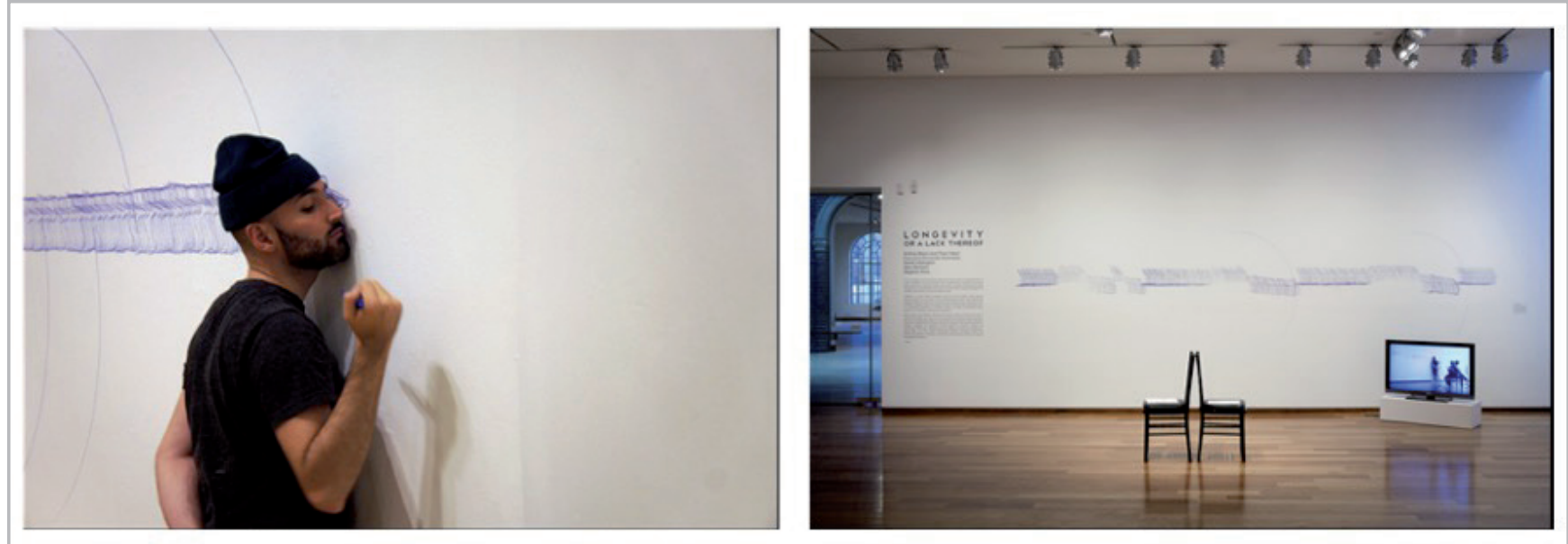

Figura/Figure 5.- spatial profiling... (2009-). Francisco-Fernando Granados. Performance, site-specific drawing; (izq.) imagen de Rob Modafferi. Iteración realizada por el artista en Berrie Center for Performing and Visual Arts. Ramapo College (dcha.) spatial profiling... (extendida) 2018. Instalación de dibujo, performance para la cámara, readymades, dimensiones variables. The MacLaren Art Centre, Barrie ON parte de Longevity or a Lack Thereof. Performado por Tyler Durbano, Luc Fortin, y Anna Lee. Imágenes propiedad de Francisco-Fernando Granados. / spatial profiling.... (2009-). FranciscoFernando Granados. Performance, site-specific drawing; (left) image by Rob Modafferi. Iteration made by the artist at Berrie Center for Performing and Visual Arts. Ramapo College (right) spatial profiling.... (extended) 2018. Drawing installation, performance for camera, readymades, variable dimensions. The MacLaren Art Centre, Barrie ON part of Longevity or a Lack Thereof. Performed by Tyler Durbano, Luc Fortin, and Anna Lee. Images property of Francisco-Fernando Granados. Rights of use are granted to the author of this article.

Con la documentación que se genera gracias a las conversaciones mantenidas entre artista y conservadora, se han establecido una serie de parámetros que servirán en un futuro para las nuevas iteraciones y la conservación de esta performance. Además, se han incluido elementos que el artista quiere controlar para que la obra siga siendo la misma. Lo que en las estrategias propuestas por la Tate se denominan elementos constantes (Lawson, Finbow, Harvey et al. 2016-2021). "La versión que se escoja será la buena" algo que Esther Ferrer le dijo a Francisco-Fernando Granados cuando él, en verano de 2019 en Toronto, re-actuó Recorrerun cuadrado de todas las formas posibles obra de Esther Ferrer. En el transcurso de la entrevista y siguientes conversaciones se habló de otras obras suyas y de conceptos de conservación aplicados a toda su trayectoria artística. Con todas estas conversaciones, Granados se ha hecho consciente de qué parámetros le interesa conservar de su obra y cómo algunas obras pueden simplemente desaparecer, otras deben desaparecer y algunas deben quedar como un archivo de lo que fueron [Figura 6].

Por lo tanto, el artista está tomando decisiones sobre su obra pasada, su documentación, los objetos y "restos" de su performance y todo el trabajo que está realizando actualmente, gracias a las reflexiones que conjuntamente se llevaron y se siguen llevando a cabo.
A series of parameters have been established with the documentation generated by the conversations between the artist and conservator. They will serve in the future for new iterations and the conservation of this performance. In addition, elements that the artist wants to control so that the work remains the same have been included. In Tate's strategies, these elements are called constant elements (Lawson, Finbow, Harvey et al. 20162021). "Whichever version is chosen will be the good one," Esther Ferrer told Francisco-Fernando Granados when he, in summer 2019 in Toronto, re-enacted Recorrer un cuadrado de todas las formas posibles work by Esther Ferrer. In the interview and following conversations, other works of his and conservation concepts applied to his entire artistic trajectory were discussed. With all these conversations, Granados has become aware of what parameters he is interested in preserving from his work and how some works can disappear, others should disappear, and some should remain as an archive of what they were [Figure 6].

Therefore, the artist is making decisions about his past work, his documentation, the objects and remains of his performance and all the work he is currently doing, thanks to the reflections that were and are being carried out together. 


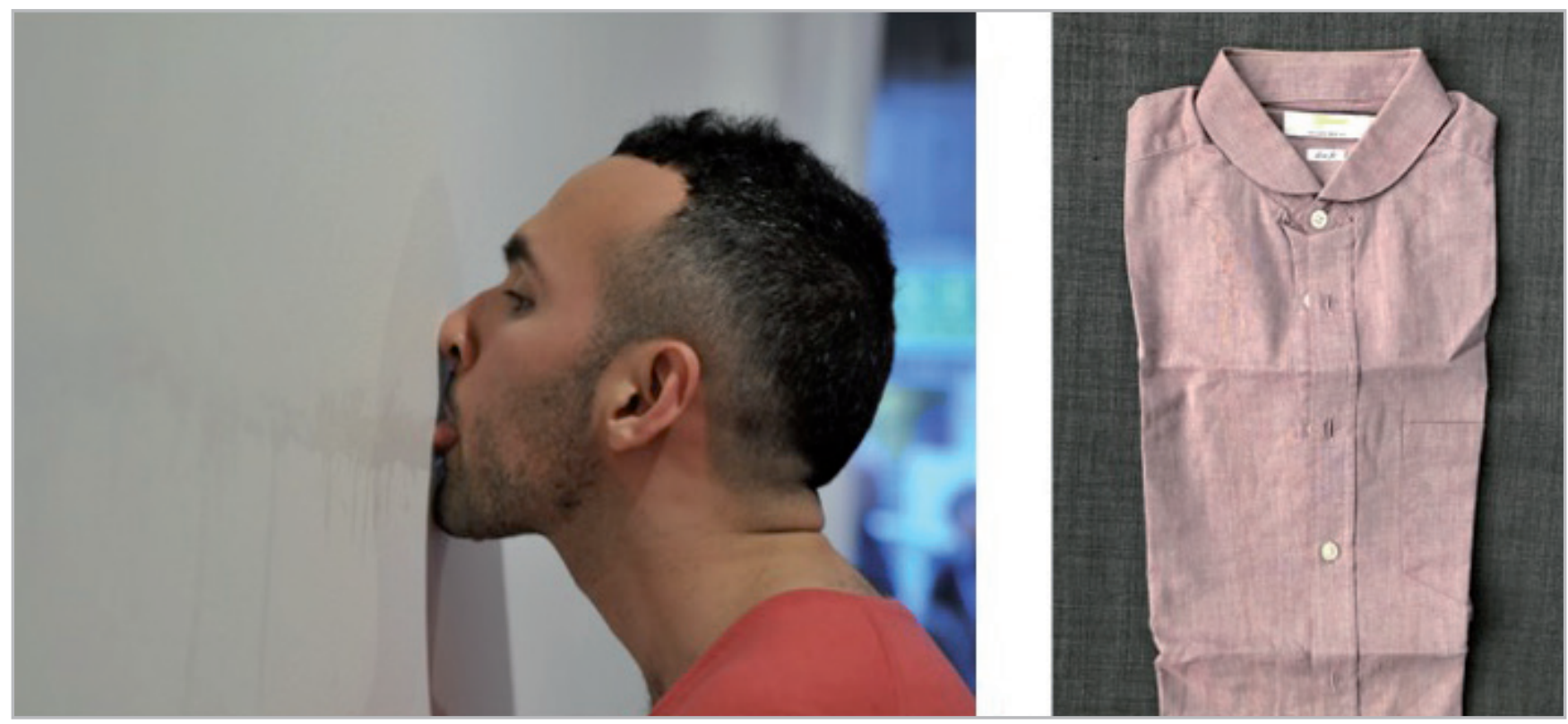

Figura/Figure 6.- I have only ever been a lover in English (2010-13). Performance, dibujo site-specific; Francisco-Fernando Granados. (izq.) Imagen realizada por Henry Chan, una de las primeras iteraciones de esta performance (dcha.) Camisa utilizada en una de las iteraciones con restos de saliva. Objeto archivo. Imágenes propiedad de Francisco-Fernando Granados. / I have only ever been a lover in English (2010-13). Performance, site-specific drawing; Francisco-Fernando Granados. (Left) Image made by Henry Chan, one of the first iterations of this performance. (Right) Shirt used in one of the iterations with traces of saliva. Archival object. Images property of Francisco-Fernando Granados. Rights of use are granted to the author of this article.

\section{Conclusiones}

Tras el análisis del trabajo realizado con artistas emergentes y de media carrera se puede afirmar que las intervenciones directas, a través de entrevistas y conversaciones, han ayudado a lxs artistas, a ser conscientes de su trabajo y de las posibilidades que la conservación les ofrece.

La concienciación, es la verdadera herramienta de conservación preventiva, eso y la muestra de cariño y respeto que la conservadora (y escritora de este ensayo) trata de establecer como primera norma de comunicación. No juzgar, mostrar mucho respeto y cariño, han sido los detonantes para abrir las puertas a la conservación preventiva activa.

Lxs artistas que han participado hasta ahora, se han mostrado agradecidxs y han implementado prácticas conscientes en su trabajo que derivan en la conservación preventiva de sus obras.

Aunque parece quedar claro que la concienciación y las sinergias que se crean al incluir a las personas artistas en el proceso de conservación son extremadamente necesarias, con resultados a futuro muy favorables, es verdad que Ixs artistas siguen siendo fieles a su proceso creativo y no anteponen la conservación a la intencionalidad.

A pesar de todo, como ya es sabido, no existe un modelopara-todos así que nada de lo expuesto en este artículo debe tomarse como verdad absoluta, sino como aportación y crítica para mejorar. Nunca es demasiado pronto para pensar en conservar el trabajo de unx artista.

\section{Conclusions}

After analyzing the work done with emerging and midcareer artists, it can be affirmed that direct interventions, through interviews and conversations, have helped artists to become aware of their work and the possibilities that conservation offers them.

Awareness is the proper tool of preventive conservation, that and the show of affection and respect that the conservator (and writer of this essay) tries to establish as the first rule of communication. Not judging, showing a lot of respect and affection have been the triggers to open the doors to active preventive conservation.

The artists who have participated so far have expressed their gratitude and have implemented conscious practices in their work that result in the preventive conservation of their creations.

Although it seems clear that the awareness and synergies created by including artists in the conservation process are extremely necessary, with very favourable future results, it is true that artists remain faithful to their creative process and do not put conservation before intentionality.

However, as we all know, there is no one-size-fitsall model, so nothing in this article should be taken as absolute truth, but as a contribution and criticism for improvement. It is never too early to think about preserving an artist's work. 


\section{Agradecimientos}

Este trabajo no existiría sin la generosidad de todxs Ixs artistas que han confiado en mí y han mantenido una actitud de curiosidad y colaboración.

\section{Notas}

[1] Perspectives- Art, Inflammation and Me y PerspectivesArt, Liver Diseases and Me, fueron dos proyectos de arte comisionado en alianza entre la farmacéutica norte americana AbVie y la Cátedra Arte y Enfermedades de la Universitat Politècnica de València dirigida por Pepe Miralles (UPV). Estos dos proyectos duraron desde 2103 hasta 2016, (del Fresno-Guillem, R., 2017: 3)

[2] Véase como ejemplo la convocatoria de la Universidad de Loyola Andalucía, III Certamen de Creación Joven Artistas Emergentes 2021. http://creacionjovenloyola.com/

[3] Para no crear confusión se adjunta la definición de conservación preventiva establecida por ICOM-CC: Preventive conservation - all measures and actions aimed at avoiding and minimizing future deterioration or loss. They are carried out within the context or on the surroundings of an item, but more often a group of items, whatever their age and condition. These measures and actions are indirect - they do not interfere with the materials and structures of the items. They do not modify their appearance. [consulta: 5/5/2021].

[4] Estos datos son extraídos de la experiencia trabajando directamente con artistas emergentes y de media carrera de programas académicos reglados, asociaciones, agrupaciones, galerías de arte autogestionadas y otro tipo de centros.

[5] Se quiere abrir un paréntesis aquí para dar a entender que hay elementos que no dependen de la mano de los participantes (conservadxr-artista). Por ejemplo, las obras en soporte tecnológico o realizadas en materiales no testados nos abren un infinito de conjeturas y suposiciones que el futuro puede demostrar erróneo. Así pues, se es consciente de las limitaciones en la apertura hacia la concienciación de las personas creativas. Limitaciones por parte de lo desconocido que está por venir y limitaciones personales porque no sabemos todo, sobre todo.

[6] Entrevista publicada en TestimoniArt, realizada el 2 de junio de 2013.

[7] Ley 16/1985, de 25 de junio, del Patrimonio Histórico Español. Artículo 36. 1. Los bienes integrantes del Patrimonio Histórico Español deberán ser conservados, mantenidos y custodiados por sus propietarios o, en su caso, por los titulares de derechos reales o por los poseedores de tales bienes.

\section{Acknowledgments}

This work would not exist without the generosity of all the artists who have trusted me and have maintained an attitude of curiosity and collaboration.

\section{Notes}

[1] Perspectives- Art, Inflammation and Me y Perspectives- Art, Liver Diseases and $M e$, were two commissioned art projects in alliance between the North American pharmaceutical AbVie and the Chair Art and Diseases of the Universitat Politècnica de València directed by Pepe Miralles (UPV). These two projects lasted from 2103 to 2016, (del Fresno-Guillem, R., 2017: 3).

[2] See as an example the call for proposals by the Universidad de Loyola Andalucía, III Certamen de Creación Joven Artistas Emergentes 2021. http:// creacionjovenloyola.com/

[3] In order not to create confusion, the definition of preventive conservation established by ICOM$\mathrm{CC}$ is attached: Preventive conservation - all measures and actions aimed at avoiding and minimizing future deterioration or loss. They are carried out within the context or on the surroundings of an item, but more often a group of items, whatever their age and condition. These measures and actions are indirect - they do not interfere with the materials and structures of the items. They do not modify their appearance. [consulted: 5/5/2021].

[4] These data are drawn from experience working directly with emerging and mid-career artists from formal academic programs, associations, groups, self-managed art galleries and other types of centers.

[5] We want to open a parenthesis here to imply that there are elements that do not depend on the hand of the participants (conservator-artist). For example, the works in technological support or made in untested materials open an infinity of conjectures and assumptions that the future may prove wrong. Thus, one is aware of the limitations in the openness to the awareness of creative people. Limitations on the part of the unknown to come and personal limitations because we do not know everything about everything.

[6] Interview published in TestimoniArt, conducted on June the 2nd, 2013.

[7] Law 16/1985, June 25 de, of the Spanish Historical Heritage. Article 36. 1. The property forming part of the Spanish Historical Heritage must be conserved, maintained, and guarded by its owners or, as the case may be, by the holders of rights in rem or by the possessors of such property. 
prácticas artísticas están en el contexto de lo Queer, se usará el artículo le/elle y terminación en e para referirse a elle.

[9] Francisco-Fernado Granados define cuerpospolíticos como aquellos que en sí mismos llevan una connotación migrante, de identidad, de cambio, mutación, reflexión social u otras acepciones. En cierto modo un cuerpo político podría ser cualquier persona, porque todxs acarreamos alguna connotación, pero en este caso es más concreto a las identidades fluctuantes por la administración y lo social. practices are in the context of Queer, the form they/their in a singular form will be used to refer to they.

[9] Francisco-Fernado Granados defines political bodies as those that in themselves carry a connotation of migration, identity, change, mutation, social reflection, or other meanings. In a certain way a political body could be any person, because we all carry some connotation, but in this case, it is more specific to the fluctuating identities due to the administration and the social.

\section{Referencias /References}

ART AL QUADRAT, https://www.artalquadrat.net/portfolio/limbo-economico-en-tres-actos-2014/ [consulta: 7/5/2021].

BEERKENS, L.,'T HOEN, P., HUMMELEN, Y., et al. eds. (2012). The artist interview. For conservation and presentation of contemporary art. Guidelines and practice. Heyningen: JAP SAM Books.

CIANCI, L. (2012). The Blackaeonium Project: Workspace/Keeping place -An Archival Continuum of Creative Practice. Victoria, Australia: RMIT University.https://exegesis.blackaeonium.net [consulta: 8/5/ 2021].

CIANCI, L. (2017). "Small acts of resistance: teaching young and emerging artists sustainable preservation strategies for contemporary creative practice", Archives and Manuscripts, 45/3: 216-236. https://www.tandfonline.com/doi/full/10.1080/01576895.2017.1376286 [consulta: 7/5/2021].

COCO RIOT (GUZMÁN). https://www.cocoriot.com/ [consulta: 7/5/2021].

Del FRESNO-GUILLEM, R. (2017). La entrevista al artista emergente como modo de conservación preventiva. Estudio aplicado a los proyectos Perspectives-Art, Inflammation and Mey Perspectives-Art, liver Disesases and Me. [Tesis doctoral no publicada]. Valencia: Universitat Politècnica de València.

Del FRESNO-GUILLEM, R. (2020) “Conscienciar com a estratègia de conservació preventiva. Quan l'entrevista a l'artista es converteix en un mitjà de prevenció i col•laboració. Coco Guzmán artista dels invisibles, cas de treball. Conservació preventiva-activa". Unicum, 19: 49-59. https://www.raco.cat/index.php/UNICUM/article/view/385201 [consulta: 9/05/2021].

DOMINGUEZ-RUBIO, F. (2020). Still Live. Ecologies of the Modern Imagination at the Art Museum. Chicago; London: The University of Chicago Press.

FRANCISCO-FERNANDO GRANADOS http://francisco-fernando-granados.blogspot.com/[consulta: 8/5/2021]

GUZMÁN-RIOT, C. (2021) "Disidencia material. Manchémonos, arruguémonos". En Con Tacto. Políticas y Poéticas de la tocabilidad. 12 de marzo-1 de junio. Sala Universitas y Sala Gris, Universidad Miguel Hernández de Elche. (Catálogo de exposición). Vila, F. (dirección) Edita La Generalitat Valenciana, 21-25.

LAWSON, L., FINBOW, A., HARVEY, D., et. al. 'Strategy and Glossary of Terms for the Documentation and Conservation of Performance', published as part of Documentation and Conservation of Performance (March 2016 - March 2021), a Time-based Media Conservation project at Tate, https://www.tate.org.uk/about-us/projects/documentation-conservation-per.... [consulta 10/05/2021].

ONTARIO ARTS COUNCIL, Visual Artists Creation Projects. https://www.arts.on.ca/grants/visual-artists-creation-projects [consulta: 7/5/2021].

QUABECK, N. (2021). "Reframing the Notion of "The Artist's Intent": A Study of Caring for Thomas Hirschhorn's Intensif-Station (2010) ". Journal of the American Institute for Conservation, 1-15. https://doi.org/10.1080/01971360.2020.1826151

RIVENC, R., van BASTEN, N., and LEARNER, T. (2017). In condensed form: "The Artist Dialogues series at the Getty Conservation Institute". In ICOM-CC 18th Triennial Conference Preprints, Copenhagen, 4-8 September 2017, ed. J. Bridgland, art. 0908. Paris: International Council of Museums.

STIGTER, S. (2016). “Autoethnography as a new approach in conservation. Studies in Conservation, 61 (sup 2), $227-232$. 
TestimoniArt, base de datos de artistas. https://ruthdelfresno.com/artists-database-1 [consulta: 8/5/2021].

UNIVERSIDAD DE LOYOLA, Andalucía, Artistas Emergentes 2021. http://creacionjovenloyola.com/ [consulta: 7/5/2021].

VAN DE VALL, R. (2015). “Documenting Dilemmas. On the Relevance of Ethically Ambiguous Cases." En Revista de História da Arte, 4: 7-17.

VAN DE VALL, R., HÖLLING, H., SCHOLTE, T. y STIGTER, S. (2011). "Reflections on a Biographical Approach to Contemporary Art Conservation.” En Proceedings of ICOM-CC 16th Triennial Conference. Lisbon, September 19-23. Preprints, edited by Janet Bridgeland, 1-8.

VoCA, Voices in Contemporary Art, https://voca.network/ [consulta: 8/5/2021]

WIELOCHA, A. (2017) “The Artist Interview as a Platform for Negotiating an artwork's possible Futures" En Art and Documentation 17: 47-57. https://www.journal.doc.art.pl/pdf17/Art and Documentation 17 all.pdf [consulta 8/5/2021]

WIELOCHA, A. (2021) Collecting Archives of Objects and Stories: On the lives and futures of Contemporary art at the museum. Tesis doctoral. Faculty of Humanities (FGw). Institute Amsterdam School for Heritage and Memory Studies (AHM). https://dare.uva.nl/search?identifier=9916bb82e5f9-4a78-9266-d47ff292104a [consulta 8/5/2021]

\section{Autor/es}

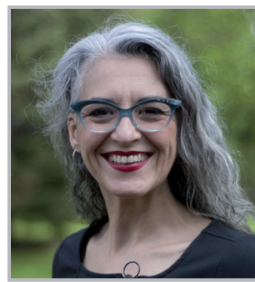

Ruth del Fresno-Guillem

ruthdelfresno@gmail.com

Testimoniart Toronto, Canadá

https://orcid.org/0000-0002-9804-9640
Ruth del Fresno-Guillem, concienciadora y conservadora de arte contemporáneo en práctica independiente, vive en Toronto, Canada. Su trabajo está vinculado a colecciones privadas, proyectos de arte público y trabajo con artistas emergentes. Ha centrado su atención en la voz del artista, y es una defensora activa de la conservación con el propósito de crear conciencia entre Ixs artistas emergentes y Ixs profesionales del arte a través de presentaciones públicas y conferencias. le interesa especialmente la intencionalidad y establecer una conexión con el artista que le ayude a entender la idea de deterioro que preocupa a cada persona creadora en particular. En 2017 se doctoró en la Universitat Politècnica de València con una tesis centrada en el uso de la entrevista aplicada a un grupo de artistas emergentes para establecer protocolos de conservación preventiva. La entrevista fue también el eje de estudio en su TFM. En ese caso aplicada a tres artistas conceptuales catalanes y sus Performances. Colabora activamente con VoCA, Voices in Contemporary Art, con base en NY, para los que realizó la entrevista pública a la artista cubana Gladys Triana enero 2020. Como investigadora ha participado en diversos proyectos que involucran la entrevista al artista, la conservación de Performance Art y las aproximaciones éticas inclusivas del arte contemporáneo. Ha participado en conferencias sobre conservación de arte contemporáneo internacionales, como AIC (American Institute of Conservation) o Traverso 2021. U otros eventos que nada tienen que ver con conservación, como hizo para la feria de arte contemporáneo Urvanity el pasado Mayo o UAAC, en Canadá donde ha hecho visible la disciplina de conservación. Es miembro del grupo de trabajo de Arte contemporáneo y de nuevos Medios del GE-IIC, TACG (Toronto Area Conservation Group) así como AIC, CAC (Canadian Art
Conservation), INCCA. Ha creado una base de datos abierta en wwwruthdelfresno.com, bajo el nombre de Testimoniart, donde publica regularmente las entrevistas que realiza.

Artículo enviado el 16/11/2021 Artículo aceptado el 29/11/2021

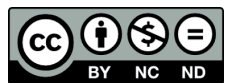

https://doi.org/10.37558/gec.v20i.1081 